DOI: $10.17951 / 1 r p .2020 .39 .2 .23-37$

\author{
Teresa Zubrzycka-MaciąG \\ Uniwersytet Marii Curie-Skłodowskiej \\ Instytut Pedagogiki \\ ORCID - 0000-0002-8942-0567 \\ Piotr Goliszek
}

Katolicki Uniwersytet Lubelski im. Jana Pawła II

ORCID - 0000-0002-3821-0439

\title{
THE PERSONAL ASPECT OF THE MORAL AND AXIOLOGICAL UPBRINGING OF CHILDREN AND ADOLESCENTS
}

\begin{abstract}
The deficit of value in social life causes concern for the fate of the future generations. Upbringing, defined as preparing a human for life and shaping their personality in the particular social and civilizational reality is the main vector of value. Timeless, universal values, determining the existence of the world guard life and its quality. Thus, one of the most important goals of upbringing is to help children and adolescents in shaping a value system which will be the cornerstone of their life. Taking into account the meaning of value in shaping a young person's personality, this paper deals with how upbringing for value is carried out by teacher and educators. Assuming that moral shaping has purpose only when it serves a particular human as an individual seeking fulfillment, we present the essence of personalized moral upbringing, i.e. as a process connected to presenting the rules of a moral existence, with raising people to freedom and responsibility, with shaping consciousness and character, acting morally and truly becoming a person.
\end{abstract}

Keywords: person, personalism, moral values, education

\section{INTRODUCTION}

Values sensustricto exist only in the personal universe of a given human. A human as an individual discovers the rich worlds of qualitatively differentiated values. Values are the indicator of human thoughts, attitudes and behaviors. They define 
who the person is, how they live and how they treat other people. Values are the criterion for initiating all human endeavors, which are the basis for integrating an individual into the society, conditioning the judgment of others and events. They express a person's wants, they make a certain final sense of reality and show what is truly important (Nowak 2000).

The adopted system of values determines the structure of a human's life. A correct hierarchy helps fully answer the questions about the meaning and goal of one's existence. The lack of a system of values in individual and societal life results in moral chaos, wrong choices and a lack of satisfaction from life. Values are the pillars that support the social, personal and communal existence.

Along with the rise of civilizational development, digital technology and consumptionism we observe a crisis of moral values among young people, reflected in lack of moral consciousness and disregard for the rules and moral norms in everyday conduct.

The teachers and educators face an extremely difficult challenge, as they need to prepare young people to be aware, active and engaged in social and vocational life. Thus, it is important to discuss the choice and execution of values in the upbringing process in such a way that it guarantees preserving human existence. In reality it is all about introducing students to the world of universal values, that are "based on good in the absolute sense. They are autotelic. They are characterized by commonness and permanence. They have been shaped in the development of humanity. They might not be accepted by all humans in at all periods of time and all over the world, yet they are common enough they can be considered universal" (Denek 2015, p. 21).

\section{THE ROLE OF VALUE IN UPBRINGING}

„Value” - as the basic category of axiology - is defined in pedagogy as everything that is important and dear to an individual and society, that is connected to positive feelings and human aspirations (Lobocki 2002, p. 72).

Values are the basis of setting pedagogical goals, thus the choice and implementation decision in the upbringing process conditions the effectiveness of upbringing efforts directed at shaping the personalities of children and adolescents.

Upbringing for values should include referring these values to life, so that one can be shown their practical - not solely theoretic - meaning. When selecting the values that are the sources of the pedagogical goals in schools one should particularly see that moral relativism is avoided. The basic task of upbringing for value should be teaching the pupils how to discern which values are means to an end 
and which are the end themselves. Thus, it is important that the pupils correctly discern which values are consumptional or material and which are moral. The pope John Paul II mentions in his teachings that: „There are values, such as personal dignity, moral and intellectual justice, religious freedom, protecting one's family, openness and respect for life, solidarity, helping each other and being involved, respecting the rights of minorities, that are innate to every human's nature, and which have been defined and proclaimed thanks to Christianity. These values are the cornerstone of stability andevery nation's true greatness " (John Paul II 2003).

Moral values serve the development of a human being most fully and as such they are exceptionally important in the upbringing process. Being tightly intertwined with the ontological nature of a person they decide about their personal development. "Respecting moral rules and putting into practice personal and moral values strengthens and enriches the individual humanity of each person and is a step towards meeting the most important needs and regularities of development in both individual and collective existence in all their predominant forms" (Cichon 1996, p. 15). The theoretical reasons for the pedagogical influence should be based on understanding the point and appreciating its impact. In accordance to the above the teachers and educators, while respecting the dignity and individuality of each pupil, should be concerned with introducing the young generation into a world of universal values, approved by culture, tradition and society, enlightening them with ideas and sense of social sensitivity, teaching them responsibility, openness and tolerance and encouraging to seek self-fulfillment and aid others (c.f. Pilch 1999).

Moral values are not dependent on legal solutions. It is the task of educators to help their pupils not only to discover moral values, but also to show their connection with the meaning and purpose of human life; to allow pupils to understand that values are arranged in a specific system and have an objective hierarchy. Upbringing for values then reveals them in general and directs the pupils towards them when the student is able to observe said values being applied in life and then they can independently and voluntarily implement them themselves. It is therefore extremely important for adults to help the children build their own hierarchy of values, in which the attitude and life of parents, catechists, educators and teachers seem to play the most important role.

\section{THE ESSENCE OF MORAL EDUCATION}

A human is not born "morally ready", but becomes so gradually, learning the moral good accordingly to the stages of their development. Theyexpress themselves as a human being through truthful choices and responsibility for their life. 
Effective moral education should include both the provision of knowledge about morality, as well as deepening emotional sensitivity and showing the motives and effects of moral behavior, which determine the formation of responsibility (Górniewicz 2005). Therefore, moral education should cover three personal spheres of the human being, i.e.: the cognitive sphere allowing the intellectual assimilation of certain norms; the emotional-voluntary sphere responsible for accepting and internalizing norms and expressing readiness to include them in one's own life and the behavioral sphere allowing the manifestation of behavior consistent with approved normative content (Dudziak 2016).

When shaping one's conscience, one must not forget that there are certain stages in the development of moral judgments. Research conducted by psychologists casts light upon this topic. For example, Carl G. Jung made a distinction between moral (heteronomic) and ethical (autonomous) conscience. Freud's discovery of "Superego" is also significant. These achievements have allowed L. Kohlberg to carry out research which resulted in distinguishing three levels and six degrees of moral consciousness and the moral evaluations undertaken on that basis:

1. The pre-conventional level falls around the age of 4-7 years and includes the stage of punishment and obedience (heteronomic morality - level I) and the stage of instrumental relativism (instrumental-hedonistic morality - level II). Children at the first level of moral development evaluate what is good and bad on the basis of physical consequences to their actions. So they try to obey orders and prohibitions, and thus avoid punishment. When at the second level of moral development, children evaluate their own moral behavior according to theability to satisfy their own needs. Morality is interpreted here in a purely pragmatic manner.

2. The conventional level falls between 7-11 years old and includes the 'good child' stage (interpersonal conformism - level III) and the social system and conscience stage (orientation of law and order - level IV). The dominant value here is striving to meet the expectations of parents, teachers or peer group, regardless of the physical consequences of the act. This attitude manifests itself primarily in loyalty to the existing order and expectations. Children at the third level of development evaluate their behavior according to what others think about it, while at the fourth level, authority and fixed and strict rules of conduct are important criteria for moral evaluation. Therefore, in a child's eyes to act morally is to follow the social order. The behavior of the child is devoid of any deeper reflection, so it happens that, while being in accordance with the rules, in certain situations it is objectively wrong.

3. The post-conventional level starts at 12 years old and includes the stage of social contract (stage V) and universal ethical principles (stage VI). By 
reaching this level of moral development, a human strives to internalize universally accepted principles and values. It is characteristic for stage $\mathrm{V}$ to seek a balance between personal views based on universal principles and the moral norms represented by society. However, these norms are understood in a flexible way, according to one's personal moral sense. The last, sixth stage of moral development is manifested by the ability to identify the principles accepted by the majority and minority of society, to define the moral principles one follows and to compare them with those recognized by others. At this stage of development, moral evaluations are inspired by internally accepted and universally prevalent basic moral principles (see Czyżowska 2008, Dudziak 2016).

The level of a pupil's moral development determines the ways and methods of educational influences that serve to introduce children and adolescents to the world of moral values. For this reason, moral education is distinguished into descriptive and normative sense.

Moral upbringing in the normative (evaluatory) sense means instilling in children and young people moral norms, principles and values whose acceptance and implementation ensures they will be moral. It is assumed here that the teacher knows which moral guidelines are useful and necessary in life. Thus, the teacher passes on moral norms and values as mandatory. In this situation, the teacher's task is to convince pupils of the validity of such norms and values and to persuade them to act accordingly. This type of moral education seems to be effective only for younger children, who in order to learn to live with other people need clearly defined rules of conduct and their consistent strengthening through an appropriate system (Łobocki 2002, p. 14).

Moral upbringing in a descriptive (neutral) sense is aimed at familiarizing the pupils with various manners of moral behavior, without suggesting an unambiguous evaluation according to criteria adopted by evaluators. It is therefore a matter of developing the moral awareness of the students, that is, their understanding of the complexity of moral problems, their ability to rationally justify the moral norms, principles or values they accept. The teacher's task in this case is to arrange discussions on the problems which will lead the pupils to argument logically and in depth on their position. Such upbringing is postulated mainly for older children and youth. It is a matter of shaping an internal source morality, which is no longer the result of obedience to the norms in force in a given cultural circle, but stems from their own desire to adapt to them and accept them as their own (Lobocki 2002, p. 14).

The aim of moral education must therefore not be to subordinate children and young people to certain norms and principles, but to shape their moral attitudes, 
which manifest in the awareness of what is good or bad; in moral sensitivity and in concrete moral behavior. For this to be possible, values must not be imposed on children and young people as merely valid regularities to be followed. "Moral values require, in order to be executed, a certain sphere of human freedom of decision and action. In order to carry out values, a man must be able to act and thus express his inner needs and intentions. An enslaved act does not lead to the realization of any moral value" (Cichoń 1996, pp. 55-56).

The shaping of the relationship to values and their hierarchical order can be modified throughout life, but the most intense time for building a value system is during adolescence. Moral education of young people is not an easy task given the crisis of moral values among adolescents, as well as the character of the development of youngsters, making them particularly demanding recipients of educational services. The effectiveness of moral education is therefore determined by the quality of educational activities and their compliance with the proclaimed moral values. The proclamation of moral values must take on the character of their subtle presence among the pupils, whilstupkeeping the principle of personal and equal treatment and the teacher's testimony of the importance of values in life. The educational work should be an eloquent testimony that a person as a human proves themselves to be both a standalone and complete being as well as existing for others, a social being (Krąpiec 1993, Łobocki 2002).

According to the above, the educator should not only teach about morality, but above all show their pupils the model of a moral person. The principle of imitation must be highlighted here, completely legible and convincing. For this reason, it is necessary to appeal to responsibility in moral formation, because this sharpens the perspective of the future. The aspect of responsibility liberates moral education from an over-emphasis on obedience, and thus from an overwhelming compulsion of the moral law. Instead of an upbringing to obedience, drifting towards legalism and normativism, it is necessary, according to the personalistic line of thought, to promote an upbringing to responsibility and freedom, understood as making an effort to shape oneself (self-determination, individual sovereignty) through self-determination and self-control (Lean, 2009).

A sense of responsibility means 'a willingness to bear the consequences of one's own choices (decisions) and one's own behavior (achievements) as a result of the decisions which have been undertaken consciously and freely of external coercion) (Łobocki 2002, p. 92).

The person in charge is aware of both the mistakes and failures made, as well as their own merits and achievements. They value their actions by comparing them to universal values such as human dignity, respect, tolerance or altruism. Responsibility in this sense may be interpreted as the responsibility for oneself (one's 
own identity), for someone else (in interpersonal contacts) or for social groups. The condition for developing a sense of responsibility is to enable children and young people to experience their own subjectivity, sense of agency, individuality and independence (Łobocki 2002).

Freedom is an essential condition for responsible behavior. This value makes it possible to make an informed and voluntary choice between good and evil. Depriving someone of their liberty means depriving them of the possibility of making decisions and thus of taking responsibility for their actions. The limitation of freedom understood as deciding, choosing and resisting external pressure is the freedom of the other person, and thus freedom as a moral value refers only to choices that do not harm others. Education for freedom is therefore directly related to education for responsibility (see Łobocki 2002, Wrońska 2000).

Tolerance as a value worth striving for in the process of upbringing is identical to the recognition of other people's right to express their own views and choose their behavior "as long as they do not misappropriate the common good and personal dignity of the individual, and do not contradict anyother fundamental values" (Łobocki 2002, p. 95). Tolerance, although it is associated with the acceptance of otherness, does not therefore exclude the disapproval of socially harmful acts or views.

In moral education an important role is played by authority, which shows young people the permanence and stability of values in a world full of unclear situations, full of moral relativism. It would be best if such an authority, and at the same time a model to be followed, was the teacher themselves. Then it would be possible to show the pupils models of behaviorin various situations, and a positive feedback from the teacher-authority would have an especially motivating power to make the pupils execute their values.

The above-described possibility of using the modelling method in upbringing to values is in fact the application of the certificate strategy. This strategy consists in stimulating and triggering the mechanism of identification in the pupil, seen as an unconsciously integrating certain characteristics of the other person (educator). It is assumed here that by identifying oneself with a certain person, the pupil assimilates (or puts into practice) certain personality traits of that person and transforms them into their own according to the model given to them by the educator. The integration sometimes takes place when the person assimilates the experience of others, and through the process of incorporating them into their own life can influence the development of personality. Thanks to this strategy, the person who carries a value (a personal symbol of value) - helps another person (the pupil) to acquire and assimilate the same values. The transmission of values by the teacher is done by showing them and living in accordance with them (see 
Nowak 2008). This means - as John Paul II pointed out - that "the work of educating a person is not done through the institutions themselves, with organizational and material means, even the best ones [...] the most important thing here is again a person and their moral authority, resulting from the truthfulness of principles and the conformity of their actions with them" (John Paul II, 1988, p. 58). Therefore, what is needed are teachers - authority figures who, with their own attitude, will promote a life of high moral standards, that is, a morally mature humanity.

The realization of values will also be fostered by the use in the pedagogical process of such methods of work which strengthen the sense of subjectivity in the pupils and enable them to reach an increasingly high level of moral development in way that is safe and free of judgement.

A method of classifying values may be helpfulin moral education, as it enables the pupils to personally choose the values they consider important. This method consists of focusing on one's own life, reflecting onbehavior, attitudes or goals, and seeking answers to the question of what one considers important in one's own behavior. After the assessment of one's own system of values, accepting one's own and others' values, it is advisable to further reflect on the motives of behavior and the choices made in order to deepen awareness of personal patterns of behavior. The experience of satisfaction resulting from a positive assessment of abehavior, consistent with the values proclaimed by the pupil will strengthen their readiness to continue a specific lifestyle in regard to their own improvement and development (Chałas 2003). In this method, it is not the logical argumentation that is important but the feelings of the alumni, so it is important that the educator does not criticize, moralize or judge. The educator's task is to help young people find alternative solutions by considering each of the possibilities and paying attention to the consequences of the choices made.

Lawrence Kohelberg's method of moral reasoning (after: Trempal 1989) consists ofleading a discussion or dialogue with the pupils about various moral dilemmas, which allows for a deeper reflection on moral norms and values, including their justification by means of logical argumentation. The aim of this strategy is to rise original ideas of moral conflicts in order to break down the previous cognitive beliefs and reorganize the views at a higher level. The method consists of five stages: presentation of the moral dilemma; searching for solutions; determining the consequences of the solutions for the people concerned; determining the values hidden in the dilemma under consideration; exposing the values that prove a higher level of moral development.

The atmosphere of education also plays an important role in the upbringing for values. The personalistic influence of educators is invaluable here, among them acceptance, altruism, fair and forgiving behavior. It is also necessary to be aware of 
the general principles of conduct that are subordinate to morality and ethics and to develop the ability to judge correctly. This will serve the purpose of self-reflection and self-knowledge, and will subsequently become the basis of self-reliance. Moral education should facilitate self-insight, understanding one's strengths, faults and bad habits, and then motivate a person to carry out moral values in one's own life. What is be important here is not only to concentrate on unwanted habits in order to reduce them, but also to concentrate on the strong sides in order to develop them (Nowak 2007). Human morality has not only an individual, but also a social character, and moral development is the result of constant learning how to act and how to build relationships with other people (Coles 2004). In moral education it is helpful toencourage young people to be interested in other humans, encouraging them to make an effort to do good and overcome their own weaknesses. The most important thing in education towards values is to inspire conviction in the students that the importance of each of them as human beings, their dignity and inner richness are born when they come into contact with each other. The key in moral education is therefore to strengthen the students' sense of personal dignity and to make them sensitive to the needs of other people (Zubrzycka-Maciąg 2015).

The process of showing moral and ethical norms, teaching the principles of moral life, education for freedom, responsibility and truth, formation of conscience and character must be carried out in such a way that its final result is the good of a person. Since moral education makes sense only when it serves a human as a person and leads to their full and definitive fulfilment, moral formation is most appropriate when it is personal.

\section{THE PERSONALISTIC DIMENSION OF MORAL EDUCATION}

Moral education in the personalistic sense is not focused on idolizingthe law and legalism, it is not about enforcing obedience to norms and duties and is not moralizing either but is based on respect and acceptance of the human person. The role of educators is then to help children and young people to bring out their capacity for doing good. It is the most personal work that leads to a new quality of humanity and a high level of human existence as a person.

Only a human as a person is capable of a moral life. Therefore, morality is about man and his dignity. Where there is a lack of morality, human dignity degrades, and with it entire communities and civilizations become inhuman (cf. Kowalczyk 2006).

Personalistic moral education serves man first and foremost. It refers to the human person, thus showing the integral truth about man, about his personal existence, and indicates the paths to be followed in order to achieve the fullness 
of humanity, becoming more and more human. This is why the concept of the person occupies a very important place in the foundations of personalistic moral formation. The individual decisions of the moral education process depend on it. The truth about man is not only a collection of information about his origin and existence, but above all a process of reading him as a person.

In the context of the truth about man as a personal being, moral formation cannot consist of transmitting claims and demands, but in showing the good which is directed at a person. This principle determines the way of thinking about moral education proclaimed in the personalistic concept.

According to the personalistic approach to moral education, man cannot be treated only as an executor of the law, but as a co-host of the world invited to seek the truth about himself and multiply the good in himself for the good of others (Marek 2013). Knowing the truth and doing goodness allows man to realize his humanity and "become" a person.

In this context, it is necessary to recall the principle of the primacy of truth over freedom, which John Paul II recalled in his encyclical Veritatis Splendor. Freedom must be guided by truth. The Pope points to "freedom towards" instead of "freedom from". Freedom must be subject to (obedient to) the truth, for it is the "universal and objective norm of morality" (John Paul II 1993, p. 60). Truth enables true freedom to become a reality, "it is through this adoption of moral law that human freedom truly becomes a reality” (John Paul II 1993, p. 35).

There is an inner natural desire in humans for truth and the same orientation towards the good. The task of the educator is, therefore, to help the pupil to discover the truth, especially about man, and to understand the reality of the person, so that they may properly shape theirconduct towards the good. Moral education teaches not only how to be good, but is also good in itself, because it teaches humans to exist even more meaningfully, to be even more human. It is not a lesson in duty, but rather a kind of "instilling" in the person's upbringing that which enriches and improves their humanity and extracts from it the hidden possibilities, inner energy and potential of the person. Such an understanding of upbringing comes down to bringing out the ability to do good in a person. The personalistic understanding of moral upbringing indicates the personal order and opposes the understanding of upbringing as an organized technique of influencing the pupil. Intentional and conscious influencing with the help of a well-thought-out way and accompanying the pupil through the authenticity of personal existence and testimony is therefore one of the basic conditions of personalistic upbringing rooted in the metaphysics of the person (Szudra 2009).

The personalistic character of moral education therefore does not focus on conveying an ethical and moral code, but on helping the pupil to achieve the full- 
ness of humanity. A moral man is one who has become so because he has properly activated his own humanity. The process by which a man validates his own humanity is an expression of his personal life and the activation of his moral potential.

The very nature of morality, which exists only in the world of persons, indicates the particular value of the human person in moral formation. This is the key to understanding all that determines the full magnitude of man, his humanity and his vocation. The person here is the elementary key to the interpretation of the whole complex process of moral education, which should help to transform human life into a "new life", into a life of fullness.

Moral education has a function which integrates the whole process of education, because it effectuates the dimension of "being" and at the same time "becoming" in an ever more complete way in human development. For this to happen, the basis of personalistic moral formation must be a man as a person and his unquestionable and irrefutable dignity. In fact, the person is neither denied nor reduced, because only the person possesses within themselves what is irreducible, what is discovered and understood only in terms of subjectivity. In order to fully understand a human and, through education, to "make" themfulfill themselves, one must stop at what is irreducibility in them, exceptional and unique in every man. Therefore, in moral education, it is necessary to focus on the truth that a human is a human being a person. Only such a perception gives a true and complete picture of a human being; of a person who is a full in-self and an out-ofself being; of a unique and unrepeatable being. Every person is not only different from other people, but also experiences themselves in a different way, is aware of themselves and of the surrounding world, makes decisions in a different way and realizes them. A person always remains an existence and during this existence they constantly represent the highest value. In moral education, it is the person who is the starting point and the point of reaching. This process should start with the person and in order to eventually lead to them. Upbringing only makes sense when it serves the person and leads to their full, final fulfilment. Even situations in which a person has deficits in moral education do not cause their personhood to "disappear". The personalistic approach to the pupil is connected with the fact that they always exists in a personalistic way. Therefore, there are no people without the status of a person (Kostur 2012).

Openness to every human being, accompanied by upbringing, is an opportunity for everyone, and everyone can make theirown person through moral development. Being a person is always the life of a person, and being a person starts over and over again. It is important to remember that the existence of a person is not just an individual existence. A person always exists among people, for people and thanks to others. So for the person to exist fully it is necessary to meet with people. 
An interpersonal personal sphere is created in relation to other people and in the dialogue with other people. The contact with other people and the continuity of the dialogue with them becomes a necessary condition for a new quality of existence. No one can fulfill themselves, develop and mature physically, mentally, intellectually and morally without meeting other people. For this reason, on the ground of moral formation, the pupils need educators who are witnesses of how to make their personal-moral life a reality. They therefore need guides, a suitable atmosphere, community, including a peer environment, and unconditional acceptance. In such conditions they will not feel themselves as individuals, but as those who belong to a community of persons. Meeting other people stimulates "existential mobilization" and teaches respect for the uniqueness (Holub 2014).

Accompanying the pupil in their moral development should aim to shape such a person so that they can fulfill themselves. It should be remembered that the moral efficiency of a person must be acquired constantly. It is also important to stress the fact that, despite having an inner potential for self-determination, it is with the help of others that the ability to recognize good and evil is formed; the ability to choose what is true and to avoid what is false. It is worth recalling once again, however, that it is impossible to effectively educate morally using even the best techniques and methods if the educator is not a credible influencer. For in this whole deed the most important thing is the human being - the educator and their moral authority, resulting from a true life, i.e. one that is in accordance with the values, norms and generally accepted principles of the moral life that they preach (Goliszek 2017). What is needed, then, are educators who, in addition to transmitting moral norms and principles of conduct, transmit a "system of personal existence" and an example of how to motivate a life of high moral quality, while also showing the source of the moral order.

\section{CONCLUSION}

The importance of moral education of children and adolescents is growing with the crisis of moral values among young people, manifested by the lack of their moral awareness and the ignorance of moral principles and norms in everyday life. In the context of the above, moral upbringing requires special attention. But the point is not that the final effect of moral education should be a bare knowledge of the norms drifting towards legalism, but the authentic good of the human person. The good of a person is what makes them more self-confident and confirms their personal dignity by perfecting their own nature. Therefore, moral education should have a personal direction. 
Moral education confirms, protects and develops man as a person. Because morality is not only a question of human behavior but above all the essence of "being" a human, moral education promotes the creation of oneself as a person and the definition of one's identity.

The role of educators who take care of introducing their pupils to the world of moral values is not only to provide proper knowledge about values, but above all to help them to develop moral skills, express themselves in making the right choices and taking responsibility for their actions.

Since moral values become real in contact with others, it is important to give children and young people as many opportunities as possible to act on behalf of certain values. Therefore, the concern of all teachers and educators should be to build a climate of mutual respect, friendliness, acceptance and commitment within the group through appropriate attitudes, methods and educational forms. It will also be beneficial for carrying out values to develop students' self-government, which enables them to co-decide on various matters, make decisions and bear their consequences, stay in close interpersonal contacts, cross the borders of egocentrism or develop tolerance by understanding other people's views.

Due to the role in the moral education undertaken by teachers, it is of particular importance that the content conveyed by themis consistent with the truth of their own lives, making demands not only on students, but also on themselves, and being an example and model for their pupils.

In modern times, moral education should be understood as a necessity of the times, which should be simultaneously an apology of individual and social morality and a warning against various aberrations. Therefore, the omission or neglect of moral education by teachers and educators may mean wasting time which should be used to help young people shape their individual and social identity, which determines their psychosocial functioning and the quality of life of future generations.

\section{REFERENCES}

Chałas K., 2003, Wychowanie ku wartościom. Elementy teorii i praktyki. T. I. LublinKielce. Wydawnictwo Jedność.

Chudy W., 2009, Pedagogia godności. Elementy etyki pedagogicznej. Lublin, TN KUL. Cichoń W., 1996, Wartości. Człowiek. Wychowanie. Kraków, Wydawnictwo Uniwersytetu Jagiellońskiego, 15.

Coles R., 2004, Inteligencja moralna dzieci. Poznań, Wydawnictwo Rebis.

Czyżowska D., 2008, O celu i granicach rozwoju moralnego. „Analiza i egzystencja”, nr 8, 85-101. 
Denek K., 2015, Wartości w kontekście edukacji i nauk o niej. In: W. Furmanek, A. Długosz (eds.), Wartości w pedagogice. Urzeczywistnianie wartości. Rzeszów, Wydawnictwo Uniwersytetu Rzeszowskiego.

Dudziak U., 2016, Wychowanie moralne. In: K. Chałas, A. Maj (eds.), Encyklopedia aksjologii pedagogicznej. Radom, Polskie Wydawnictwo Encyklopedyczne, 1431-1436. Goliszek P.T., 2016, Personalistyczny wymiar katechezy. Lublin, KUL.

Goliszek P.T., 2017, Personalistic Moral Education in Catechesis. „Roczniki Teologiczne" T. 64, z. 11, 132.

Górniewicz J., 2005, Teoria wychowania (wybrane problemy). Olsztyn, Wydawnictwo OSW.

Hołub G., 2014, Osoba w labiryncie decyzji moralnych. Bioetyka w perspektywie personalistycznej. Kraków, Wydawnictwo Św. Stanisława BM.

Jan Paweł II (6.08.1993, nr 35), Encyklika Veritatis splendor o niektórych podstawowych problemach nauczania moralnego Kościoła.

Jan Paweł II (6.08.1993, nr 60), Encyklika Veritatis splendor o niektórych podstawowych problemach nauczania moralnego Kościoła.

Jan Paweł II, 1988, Przemówienie w UNESCO. W imię przyszłości kultury. Paryż 2.06.1980, nr 11. In: M. Radwan, S. Wylężek, T. Gorzkula (eds.), Wiara i kultura. Dokumenty, przemówienia, homilie. RW KUL.

Jan Paweł II, 2003, Naród trzeba budować na trwałych wartościach. Ceremonia powitalna na lotnisku. Wyspa Krk (Chorwacja), 5.06.2003, https://opoka.org.pl/biblioteka/W/ WP/jan_pawel_ii/przemowienia/krk_05062003.html [access from: 16.02.2020].

Kostur M.A., 2012, Osoba a wychowanie. Ujecie z perspektywy personalistycznej. In: W kregu inspiracji personalizmu etycznego. Kraków, „Ignatianum”, Wydawnictwo WAM, 301-317.

Kowalczyk S., 2006, Człowiek w poszukiwaniu wartości. Elementy aksjologii personalistycznej. Lublin, 165, 181-184.

Krąpiec A., 1993, Odzyskać świat realny. Lublin, RW KUL.

Łobocki M., 2002, Wychowanie moralne w zarysie, Kraków, Oficyna Wydawnicza Impuls.

Marek Z., 2013, Wychowanie religijno-moralne. In: A. Rynio, K. Braun, A. Lendzion, D. Opozda (eds.), Religijno-moralny wymiar rozwoju i wychowania. Lublin, Wydawnictwo KUL, 21-38.

Nowak M., 2000, Podstawy pedagogiki otwartej. Lublin, KUL.

Nowak M., 2007, Charakter w pedagogice. In: Leksykon Pedagogiki Religii. Warszawa, Verbinum, 39-45.

Nowak M., 2008, Teorie i koncepcje wychowania. Warszawa, Wydawnictwa Akademickie i Profesjonalne.

Pilch T., 1999, Spory o szkołę. Pomiędzy tradycją a wyzwaniami współczesności. Warszawa, Wydawnictwo Akademickie Żak. 
Szudra A., 2009, Dialogiczna etyka wychowawcza. In: W. Chudy, Pedagogia godności. Elementy etyki pedagogicznej. Lublin, TN KUL 219-222.

Trempała J., 1989, Niedyrektywna edukacja moralna: strategie prowadzenia dyskusji i klasyfikowania wartości. „Edukacja”, nr 2, 20-23.

Wrońska K., 2000, Osoba i wychowanie. Wokół personalistycznej filozofii wychowania Karola Wojtyły Jana Pawła II. Kraków, Wydawnictwo UJ.

Zubrzycka-Maciąg T., 2015, Szacunek - wartość zaniechana w pedagogice. In: W. Furmanek, A. Długosz (eds.), Wartości w pedagogice. Urzeczywistnianie wartości. Rzeszów, Wydawnictwo UR, 115-130.

Zubrzycka-Maciąg T., 2017, Wychowanie moralne we współczesnej szkole. In: J. Górniewicz (ed.), Edukacja - w stronę kluczowych wartości. Olsztyn-Białystok, Centrum Badań Społecznych UW-M, 9-20.

\section{PERSONALISTYCZNY WYMIAR \\ WYCHOWANIA MORALNO-AKSJOLOGICZNEGO DZIECI I MŁODZIEŻY}

Streszczenie: Deficyt wartości w życiu społecznym powoduje niepokój o przyszłość kolejnych pokoleń. Głównym przekaźnikiem wartości jest wychowanie, rozumiane jako przygotowanie człowieka do życia i kształtowanie jego osobowości w warunkach konkretnej rzeczywistości społecznej i cywilizacyjnej. Na straży życia i jego jakości stoją wartości ponadczasowe, uniwersalne, które warunkują trwanie świata. Jednym z najważniejszych celów wychowania jest zatem pomoc dzieciom i młodzieży w kształtowaniu systemu wartości, który będzie stanowił fundament ich życia. W artykule poruszono problematykę wartości w kontekście ich znaczenia dla kształtowania osobowości dzieci i młodzieży. Przyjmując, że formacja moralna ma sens tylko wówczas, kiedy służy człowiekowi jako spełniającej się osobie, ukazano istotę wychowania moralnego ukierunkowanego personalistycznie, tj. jako proces związany z ukazywaniem zasad życia moralnego, z wychowaniem do wolności i odpowiedzialności, z formacją sumienia i kształtowania charakteru oraz urzeczywistniania wartości moralnych i stawania się w pełni osobą.

Słowa kluczowe: osoba, personalizm, wartości moralne, wychowanie 